Supporting Information

\title{
Fabrication of Ru and Ru-Based Functionalized Nanotubes
}

\author{
Jun Chen, Zhan-Liang Tao, Suo-Long Li \\ Institute of New Energy Material Chemistry and State Key Laboratory of Functional Polymer Materials for \\ Adsorption and Separation, Chemistry College, Nankai University, Tianjin 300071, P.R.China \\ *To whom correspondence should be addressed. E-mail: chenabc@nankai.edu.cn
}

Figure S1. Schematic diagrams showing the experimental set-up (a) and the growth mechanism (b) of the template preparation for $\mathrm{Ru}$ and $\mathrm{Ru}-\mathrm{Pt}$ nanotubes.

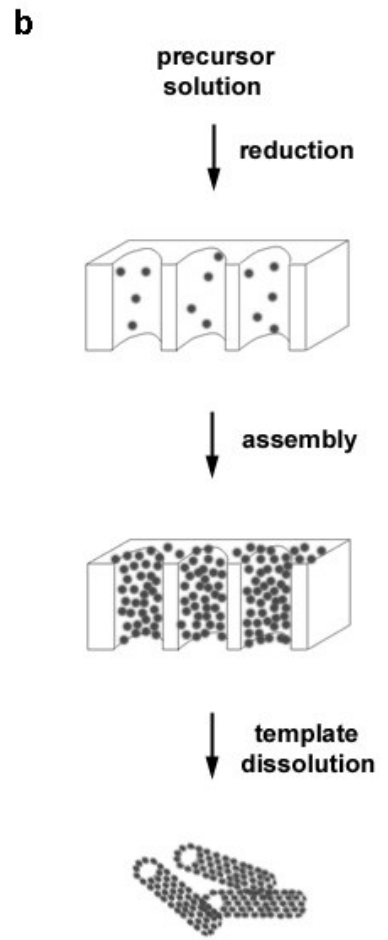

Procedure for the preparation of $\mathrm{Ru}$ and $\mathrm{Ru}-\mathrm{Pt}$ nanotubes. The $\mathrm{Ru}$ and $\mathrm{Ru}-\mathrm{Pt}$ nanotubes were prepared using a pressure-filter-template technique, which overcomes the problem of pore blocking by applying external pressure. The schematic diagrams for the experimental set-up and the growth mechanism are shown in Figures S1(a) and (b), respectively. In a typical synthesis, $0.1 \mathrm{M} \mathrm{Ru}\left(\mathrm{NH}_{3}\right)_{6} \mathrm{Cl}_{3}$ (for the preparation of $\mathrm{Ru}$ nanotubes) or $0.06 \mathrm{M} \mathrm{Ru}\left(\mathrm{NH}_{3}\right)_{6} \mathrm{Cl}_{3}+0.02 \mathrm{M} \mathrm{K}_{2} \mathrm{PtCl}_{6}$ (for the preparation of $\mathrm{Ru}-\mathrm{Pt}$ nanotubes) aqueous solutions were squeezed through an aluminum oxide template $(\Phi 10$ $\mathrm{mm}$ ) with an average inner pore diameter of $0.05 \mu \mathrm{m}$ and a length of $60 \mu \mathrm{m}$ (Whatman International Ltd). This template was first sandwiched by commercial Millipore filters and then further strengthened by placing Pt meshes on both the top and bottom sides of the sandwich and finally settled in a vertical cylindrical stainless-steel tube. A heated hydrogen-argon atmosphere was introduced into the tube with controlled volume ratio 
and flow rate, while the furnace was held at $180-260{ }^{\circ} \mathrm{C}$ for $1 \mathrm{~h}$, with alternating the squeezing and washing (by distilled water) steps.

Subsequent experiments showed that the size, shape and morphology of the Ru and $\mathrm{Ru}-\mathrm{Pt}$ nanotubes were affected strongly by the reaction conditions, which included the $\mathrm{Ru}\left(\mathrm{NH}_{3}\right)_{6} \mathrm{Cl}_{3}$ or $\mathrm{Ru}\left(\mathrm{NH}_{3}\right)_{6} \mathrm{Cl}_{3}+\mathrm{K}_{2} \mathrm{PtCl}_{6}$ concentration, the gas flow rate and its composition, and the heating temperature. For example, when the concentration of $\mathrm{Ru}\left(\mathrm{NH}_{3}\right)_{6} \mathrm{Cl}_{3}$ was higher than $0.15 \mathrm{M}$, Ru nanofibres were obtained. To prepare $\mathrm{Ru}$ nanotubes of high purity with high yield, the optimized conditions were determined to be $0.1 \mathrm{M} \mathrm{Ru}\left(\mathrm{NH}_{3}\right)_{6} \mathrm{Cl}_{3}$, a $\mathrm{H}_{2} / \mathrm{Ar}$ gas flow rate of $8 \mathrm{~mL} / \mathrm{min}$ (volume ratio of $\mathrm{H}_{2} / \mathrm{Ar} \mathrm{1:19}$ ), and a heating process at $180^{\circ} \mathrm{C}$ for $1 \mathrm{~h}$. To prepare Ru-Pt nanotubes, the optimized conditions were determined to be $0.06 \mathrm{M} \mathrm{Ru}\left(\mathrm{NH}_{3}\right)_{6} \mathrm{Cl}_{3}+0.02 \mathrm{M} \mathrm{K}_{2} \mathrm{PtCl}_{6}$, a $\mathrm{H}_{2} / \mathrm{Ar}$ gas flow rate of $10 \mathrm{~mL} / \mathrm{min}$ (volume ratio of $\mathrm{H}_{2} / \mathrm{Ar} 1: 19$ ), and a heating process at $260^{\circ} \mathrm{C}$ for $1 \mathrm{~h}$. The reduction reactions of the metal ions can be expressed as

$$
\begin{aligned}
& 2 \mathrm{Ru}\left(\mathrm{NH}_{3}\right)_{6} \mathrm{Cl}_{3}+3 \mathrm{H}_{2} \rightarrow 2 \mathrm{Ru}+6 \mathrm{NH}_{4} \mathrm{Cl}+6 \mathrm{NH}_{3} \\
& \mathrm{~K}_{2} \mathrm{PtCl}_{6}+2 \mathrm{H}_{2} \rightarrow \mathrm{Pt}+2 \mathrm{KCl}+4 \mathrm{HCl}
\end{aligned}
$$


Figure S2. Cyclic voltammogram of the Ru-Pt-core/Nafion-sheath composite nanotubes electrode (with Ru-Pt loading at about $0.2 \mathrm{mg} / \mathrm{cm}^{2}$ ) in $1 \mathrm{M}$ methanol $+0.5 \mathrm{M} \mathrm{H}_{2} \mathrm{SO}_{4}$ at $25^{\circ} \mathrm{C}$ and a scan rate of $20 \mathrm{mV} / \mathrm{s}$.

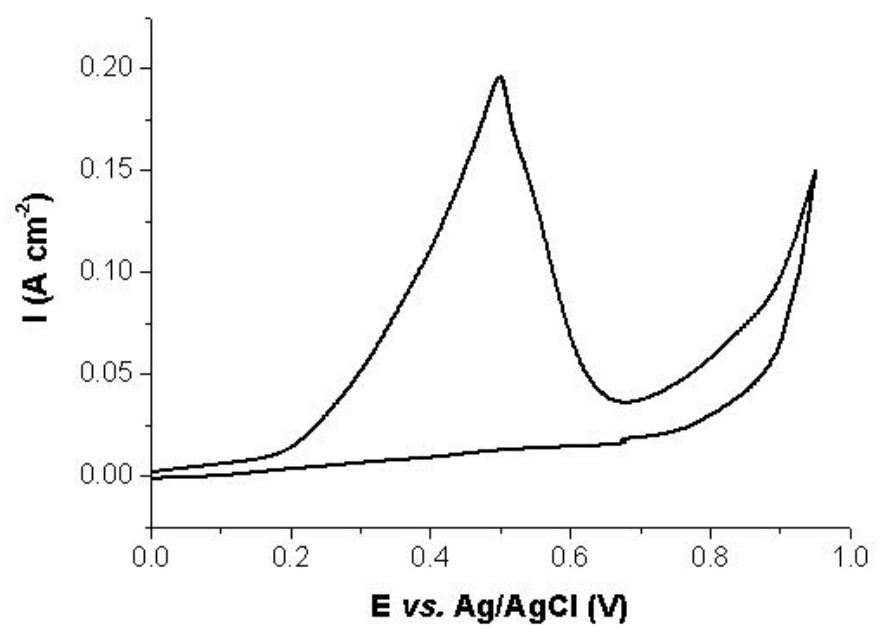

Application of Ru-Pt-core/Nafion-sheath composite nanotubes for the electrochemical oxidation of methanol. The electrode was formed by directly pressing the $100 \mathrm{mg} \mathrm{Ru}$-Pt-core/Nafion-sheath composite nanotubes to a sheet of nickel mesh at $20 \mathrm{MPa}$. The electrochemical measurements were carried out with a standard threecompartment meniscus-type electrochemical cell and contacted with freshly prepared 0.5 $\mathrm{M} \mathrm{H}_{2} \mathrm{SO}_{4}$ at $25^{\circ} \mathrm{C}$. Analysis-grade methanol was present in the electrolyte during immersion and the electrodes were equilibrated for two minutes at the immersion potential. An $\mathrm{Ag} / \mathrm{AgCl} / \mathrm{KCl}(3 \mathrm{M})$ electrode was used as the reference electrode. The sweep rate in cyclic voltammetry was $20 \mathrm{mV} / \mathrm{s}$. The electrochemical performance was investigated by means of Solartron SI 1260 Potentonstat Analyzer with 1287 Interface, which was auto-controlled by a computer. The methanol oxidation can be expressed as

$$
\mathrm{CH}_{3} \mathrm{OH}+\mathrm{H}_{2} \mathrm{O} \rightarrow \mathrm{CO}_{2}+6 \mathrm{H}^{+}+6 \mathrm{e}^{-}
$$

